\title{
Comparative study of vibration disease among operators of vibrating tools by factor analysis
}

\author{
M FUTATSUKA, ' $\mathbf{N}$ YASUTAKE, ${ }^{1}$ T SAKURAI, ${ }^{2}$ AND T MATSUMOTO ${ }^{3}$ \\ From the Department of Public Health, ' Kumamoto University Medical School, Kumamoto 860, Department \\ of Environmental Health, ${ }^{2}$ Kurume University School of Medicine, Kurume 830, and Department of Public \\ Health, ${ }^{3}$ Nagoya City University Medical School, Nagoya 466, Japan
}

ABSTRACT Principal component analysis was carried out to determine the interrelationships between subjective symptoms experienced by workers using various types of vibrating tools (brush saws (41), rock drills (39), chipping hammers (42) and chain saws (49)) and control groups (clerks (44), farmers (42)). The characteristics of the patterns of common factors extracted from these symptoms and the frequency distribution of the factor score of the main principal components were compared among the groups. From a wide variety of symptoms, a principal component related to peripheral nerves, muscles, and joints and a component related to peripheral circulation were extracted specifically and separately. The complaints of rock drillers reflected a peripheral circulatory factor and those of chain saw users presented a complex factor of nerves, muscle, and joints.

Vibration disease caused by using manual vibrating tools occurs in many occupations. This syndrome comprises not only the peripheral circulatory disturbances known as vibration induced white finger (VWF) but also disturbances of peripheral nerves, muscles, bones, and joints. A wide variety of different types of disturbance may arise from the succession of physical blows impacting on the hand holding a vibrating tool..$^{1-4}$ Among these disturbances, VWF has been examined intensively and is well described. ${ }^{56}$ Recently, however, the concept of vibration disease has been expanded to encompass the complex of symptoms associated with vibrating tools. ${ }^{7}$ The large number and the characteristic distribution of reports of these symptoms among operators of vibrating tools appear to be evidence that they are associated with certain types of tool vibration. ${ }^{8}$ Each symptom, however, has been discussed separately.

In the present study principal component analysis was carried out to determine the interrelationships among the subjective symptoms experienced by workers using various types of vibrating tools and characteristics of the patterns of common factors that were extracted from these symptoms, and the

Received 30 April 1984

Accepted 2 July 1984 frequency distribution of the factor score of the main principal components were compared for the different types of vibrating tools.

Subjects

Four occupational groups were selected as the groups exposed to vibration (1) brush saw operators

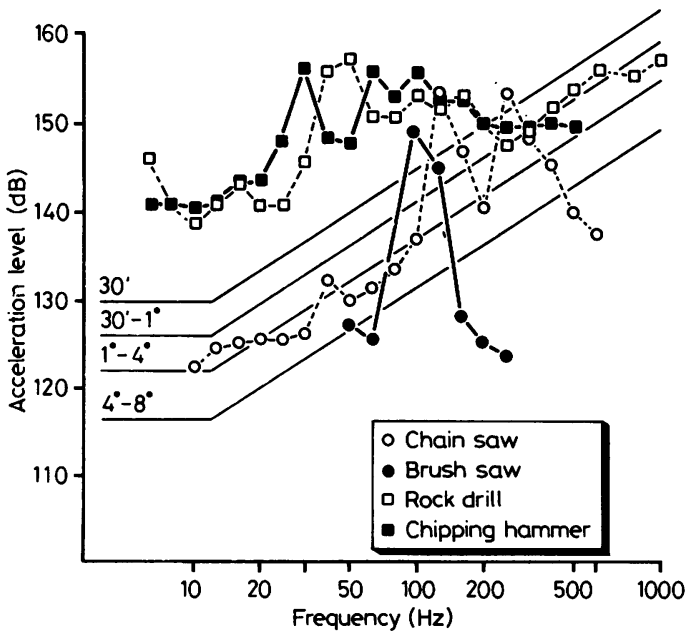

Fig 1 Vibration spectrum of vibrating tools (fore and aft). 
Table 1 Work conditions in the subject groups

\begin{tabular}{|c|c|c|c|c|c|}
\hline & Vibration exposure & Weight of tool ( $\mathrm{kg})$ & $\begin{array}{l}\text { Temperature in } \\
\text { work place } \\
\text { (winter time) }\end{array}$ & $\begin{array}{l}\text { Noise level } \\
(d b A)\end{array}$ & $\begin{array}{l}\text { Incline of } \\
\text { work place }\end{array}$ \\
\hline Brush saw & \multirow{4}{*}{$\begin{array}{l}\text { 4-6 hours/day } \\
100-120 \text { days/year } \\
2-3 \text { hours/day } \\
250-300 \text { days/year } \\
3-4 \text { hours/day } \\
250-300 \text { days/year } \\
2-4 \text { hours/day } \\
200-300 \text { days/year }\end{array}$} & $7-9$ & $-5-8^{\circ} \mathrm{C}$ & $90-105$ & $15-30^{\circ} \mathrm{C}$ \\
\hline Rock drill & & $22-33$ & $17-20^{\circ} \mathrm{C}$ & $106-117$ & Horizontal \\
\hline Chipping hammer & & $10-15$ & $-2-10^{\circ} \mathrm{C}$ & $100-113$ & Horizontal \\
\hline Chain saw & & $7-15$ & $-5-8^{\circ} \mathrm{C}$ & $105-118$ & $\underset{\text { (mountain) }}{0-20^{\circ} \mathrm{C}}$ \\
\hline
\end{tabular}

Table 2 Age and vibration exposure period of the subjects

\begin{tabular}{|c|c|c|c|}
\hline & No & $\begin{array}{l}\text { Vibration } \\
\text { exposure } \\
\text { period }(y) \\
(\text { Mean } \pm S D)\end{array}$ & $\begin{array}{l}\text { Age }(y) \\
(\text { Mean } \pm S D)\end{array}$ \\
\hline $\begin{array}{l}\text { Brush saw } \\
\text { Rock drill } \\
\text { Chipping }\end{array}$ & $\begin{array}{l}41 \\
39\end{array}$ & $\begin{array}{r}9 \cdot 3 \pm 5 \cdot 0 \\
15 \cdot 0 \pm 5 \cdot 5\end{array}$ & $\begin{array}{l}41 \cdot 9 \pm 5 \cdot 8 \\
41 \cdot 3 \pm 5 \cdot 3\end{array}$ \\
\hline $\begin{array}{l}\text { hammer } \\
\text { Chain saw } \\
\text { Clerks } \\
\text { Farmers }\end{array}$ & $\begin{array}{l}42 \\
49 \\
44 \\
42\end{array}$ & $\begin{array}{l}8.9 \pm 1.9 \\
10.2 \pm 3.6 \\
=\end{array}$ & $\begin{array}{l}42.4 \pm 5 \cdot 8 \\
45.9 \pm 2.7 \\
42 \cdot 8 \pm 5.9 \\
43.9 \pm 6 \cdot 3\end{array}$ \\
\hline
\end{tabular}

in forestry, (2) rock drill operators in a metal mine, (3) chipping hammer operators in a quarry, and (4) chain saw operators in forestry. Two control groups were also selected: (1) clerks in a regional forest office and (2) farmers with no exposure to vibration. The vibration spectra of the vibrating tools and the work conditions related to the effects of vibration are shown in fig 1 and table $1^{y-12}$; table 2 shows the exposure period and age of the subjects. As shown in table 2 , the subjects were matched for age to take account of the fact that age is a confounding factor

Table 3 Prevalence rate of complaints in subject groups

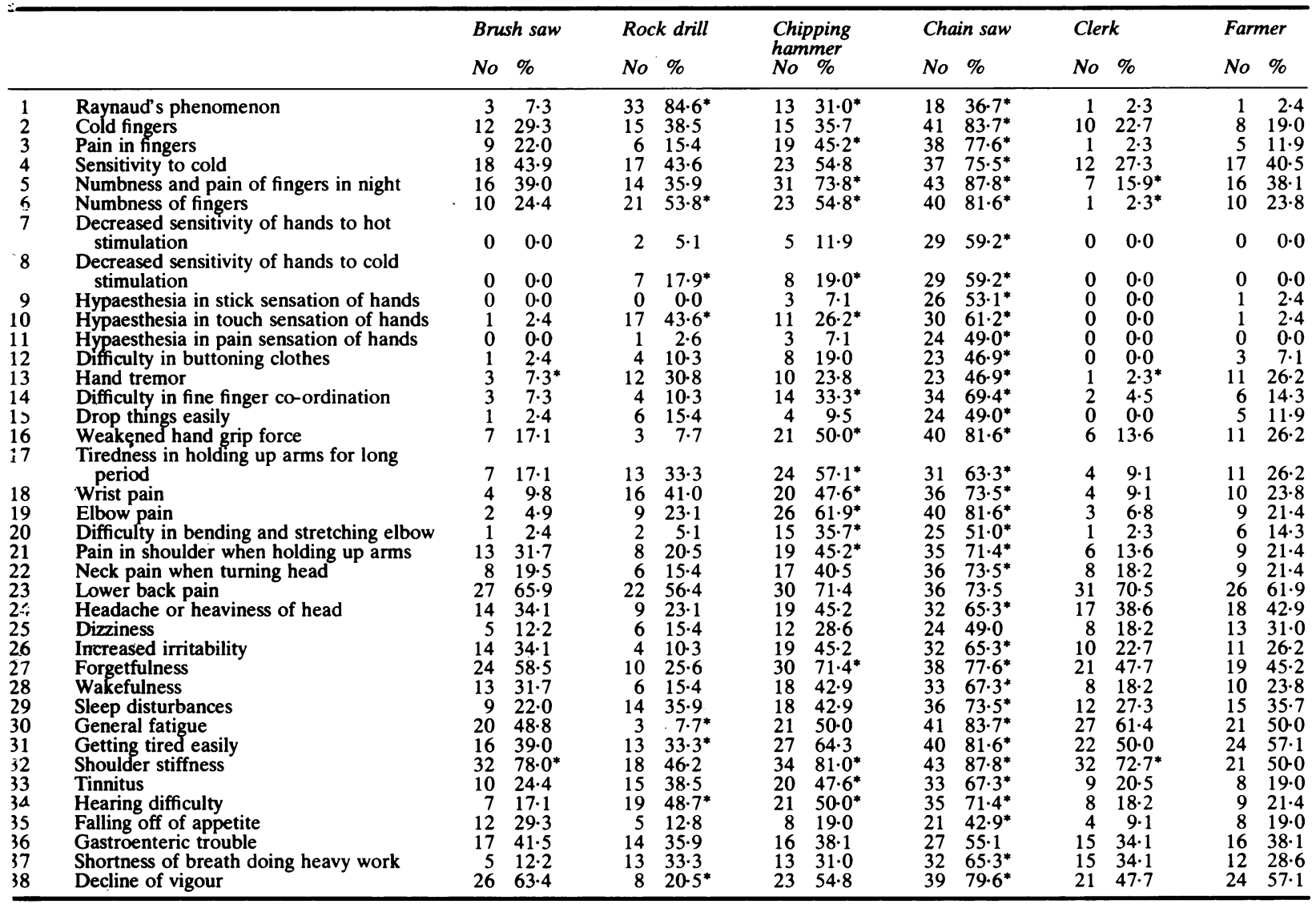

'Statistically significant at 0.05 level in comparison with farmers. 
for subjective symptoms.

\section{Methods}

All the subjects were interviewed in the middle of the 1970 s by medical staff to elicit subjective symptoms using a 38 item questionnaire designed by the medical committee of vibration disease of the Japanese Association of Industrial Health. In scoring the items in the questionnaire (shown in table 3) the following ordinal scale for rating the frequency of each complaint within one year was used: "frequently" was given a score of 2 whereas "never" and "seldom" were given a score of 1 .

The questionnaire data were analysed by factor analysis. ${ }^{1314}$ Pearson correlation coefficients between all pairs of complaints in the four exposure groups were computed, and a correlation matrix ( 38 $\times 38$ ) was obtained. This matrix was analysed using the principal factor method with iteration. The resultant factor matrix $(38 \times \mathrm{N}, \mathrm{N}=$ estimated number of factors) was rotated by the varimax method, and the new varimax factor matrix was used to categorise the 38 complaints. Factor scores for each subject in all six groups were also computed. Three factors were chosen on the basis of practical usefulness, and $48.3 \%$ of the variance was accounted for by the three extracted factors.

Some of the subjects were diagnosed as suffering from VWF or peripheral neuromuscular disorders of vibration disease from data obtained by using the method and criteria recommended by the Japanese Ministry of Labour. ${ }^{15}$

\section{Results}

\section{PREVALENCE OF COMPLAINTS}

Table 3 shows the prevalence rate of each complaint by subject group. The prevalence of Raynaud's phenomenon was $7.3 \%$ among brush saw operators, $84.6 \%$ among rock drill operators, $31.0 \%$ among chipping hammer operators, $36.4 \%$ among chain saw operators, and $2 \cdot 3-2.4 \%$ in the non-exposed groups. In general, the highest prevalence rates were found in the chain saw operators. Many types of local complaints in the hands were higher in the

Table 4 Correlation matrix among 38 items complaints in the exposure groups

\begin{tabular}{|c|c|c|c|c|c|c|c|c|c|c|c|c|c|c|c|c|c|c|c|}
\hline & $l$ & 2 & 3 & 4 & 5 & 6 & 7 & 8 & 9 & 10 & 11 & 12 & 13 & 14 & 15 & 16 & 17 & 18 & 19 \\
\hline 1 & 1.000 & & & & & & & & & & & & & & & & & & \\
\hline 2 & $0 \cdot 227$ & 1.000 & & & & & & & & & & & & & & & & & \\
\hline 3 & -0.029 & 0.499 & 1.000 & & & & & & & & & & & & & & & & \\
\hline 4 & 0.163 & 0.445 & 0.286 & 1.000 & & & & & & & & & & & & & & & \\
\hline 5 & 0.055 & 0.300 & 0.418 & 0.246 & 1.000 & & & & & & & & & & & & & & \\
\hline 6 & 0.221 & 0.409 & 0.558 & 0.255 & 0.453 & 1.000 & & & & & & & & & & & & & \\
\hline 7 & 0.056 & 0.360 & 0.460 & $0 \cdot 260$ & 0.297 & $0 \cdot 352$ & 1.000 & & & & & & & & & & & & \\
\hline 8 & 0.076 & 0.392 & 0.446 & 0.257 & 0.281 & 0.452 & 0.648 & $1 \cdot 000$ & & & & & & & & & & & \\
\hline 9 & -0.012 & 0.434 & 0.467 & $0 \cdot 216$ & 0.331 & $0 \cdot 378$ & 0.684 & 0.732 & 1.000 & & & & & & & & & & \\
\hline 10 & 0.224 & 0.427 & $0 \cdot 378$ & 0.303 & $0 \cdot 280$ & 0.459 & 0.500 & 0.727 & 0.590 & 1.000 & & & & & & & & & \\
\hline 11 & 0.033 & 0.392 & 0.423 & 0.269 & 0.290 & $0 \cdot 369$ & 0.663 & 0.716 & 0.895 & $0 \cdot 610$ & 1.000 & & & & & & & & \\
\hline 12 & $0 \cdot 056$ & $0 \cdot 360$ & 0.460 & 0.289 & 0.268 & 0.381 & 0.613 & 0.648 & 0.569 & 0.561 & 0.586 & 1.000 & & & & & & & \\
\hline 13 & $0 \cdot 138$ & $0 \cdot 331$ & 0.416 & $0 \cdot 297$ & $0 \cdot 261$ & 0.408 & 0.412 & 0.406 & 0.377 & 0.477 & 0.462 & $0 \cdot 380$ & 1.000 & & & & & & \\
\hline 14 & -0.091 & 0.459 & 0.503 & 0.339 & 0.373 & 0.447 & 0.535 & 0.597 & 0.590 & 0.554 & 0.575 & 0.596 & 0.434 & 1.000 & & & & & \\
\hline 15 & $0 \cdot 068$ & 0.290 & $0 \cdot 301$ & 0.250 & 0.288 & $0 \cdot 284$ & 0.485 & 0.464 & 0.582 & 0.486 & 0.520 & 0.520 & $0 \cdot 296$ & 0.489 & 1.000 & & & & \\
\hline 16 & -0.093 & 0.440 & 0.531 & 0.372 & 0.409 & 0.333 & 0.496 & 0.454 & 0.473 & 0.412 & 0.461 & 0.467 & $0 \cdot 319$ & 0.589 & 0.367 & 1.000 & & & \\
\hline 17 & 0.015 & $0 \cdot 226$ & 0.320 & $0 \cdot 293$ & 0.396 & 0.374 & 0.295 & 0.369 & 0.354 & 0.375 & 0.405 & 0.353 & 0.235 & 0.552 & $0 \cdot 311$ & 0.379 & 1.000 & & \\
\hline 18 & 0.174 & $0 \cdot 356$ & 0.453 & $0 \cdot 255$ & $0 \cdot 284$ & 0.526 & 0.462 & 0.550 & 0.411 & $0 \cdot 490$ & 0.399 & 0.462 & 0.410 & 0.543 & 0.421 & 0.393 & 0.372 & 1.000 & \\
\hline 19 & 0.044 & $0 \cdot 344$ & 0.490 & $0 \cdot 289$ & 0.413 & 0.394 & 0.455 & 0.543 & 0.499 & 0.480 & 0.457 & 0.426 & $0 \cdot 246$ & 0.534 & $0 \cdot 386$ & 0.502 & 0.455 & 0.468 & 1.00 \\
\hline 20 & -0.079 & 0.381 & 0.516 & 0.301 & 0.327 & 0.416 & 0.560 & 0.584 & 0.528 & 0.487 & 0.545 & 0.560 & 0.418 & 0.669 & 0.441 & 0.551 & 0.438 & 67 & 0.53 \\
\hline 21 & 0.015 & 0.368 & 0.392 & $0 \cdot 364$ & 0.444 & 0.303 & 0.324 & 0.342 & 0.386 & $0 \cdot 325$ & 0.405 & 0.411 & 0.313 & 0.552 & 0.340 & 0.427 & 0.525 & 0.490 & 0.43 \\
\hline 22 & 0.067 & 0.419 & 0.407 & 0.404 & 0.423 & 0.389 & 0.467 & 0.295 & 0.467 & $0 \cdot 350$ & 0.487 & 0.408 & $0 \cdot 352$ & 0.499 & 0.424 & 0.418 & $0 \cdot 474$ & 0.415 & 0.40 \\
\hline 23 & -0.001 & 0.179 & 0.217 & $0 \cdot 203$ & 0.257 & $0 \cdot 220$ & 0.177 & 0.069 & 0.149 & 0.035 & 0.174 & 0.055 & 0.131 & $0 \cdot 160$ & $0 \cdot 200$ & $0 \cdot 108$ & $0 \cdot 190$ & $0 \cdot 148$ & 0.23 \\
\hline 24 & 0.097 & 0.309 & 0.331 & 0.401 & 0.387 & $0 \cdot 292$ & 0.331 & $0 \cdot 269$ & $0 \cdot 297$ & 0.235 & 0.347 & $0 \cdot 360$ & $0 \cdot 295$ & 0.409 & 0.318 & 0.366 & $0 \cdot 394$ & 0.335 & 0.32 \\
\hline 25 & 0.123 & $0 \cdot 241$ & 0.350 & $0 \cdot 261$ & 0.360 & 0.399 & 0.389 & 0.267 & 0.350 & 0.325 & 0.400 & 0.357 & 0.461 & $0 \cdot 361$ & 0.305 & 0.332 & 0.353 & 0.319 & C. 31 \\
\hline 26 & -0.050 & $0 \cdot 251$ & $0 \cdot 337$ & $0 \cdot 256$ & 0.343 & $0 \cdot 289$ & 0.335 & 0.252 & 0.327 & $0 \cdot 281$ & $0 \cdot 345$ & 0.335 & 0.309 & 0.352 & 0.292 & 0.299 & 0.330 & 0.368 & 0.31 \\
\hline 27 & -0.121 & $0 \cdot 274$ & $0 \cdot 291$ & 0.416 & 0.243 & 0.214 & 0.249 & 0.266 & $0 \cdot 308$ & $0 \cdot 196$ & 0.267 & 0.279 & 0.142 & 0.362 & $0 \cdot 329$ & 0.403 & 0.367 & $0 \cdot 232$ & 0.33 \\
\hline 28 & -0.010 & 0.239 & 0.278 & 0.290 & 0.327 & 0.251 & 0.387 & 0.299 & 0.448 & $0 \cdot 296$ & 0.467 & 0.329 & $0 \cdot 300$ & $0 \cdot 394$ & 0.403 & $0 \cdot 288$ & 0.343 & 0.356 & $0 \cdot 32$ \\
\hline 29 & $0 \cdot 189$ & 0.391 & $0 \cdot 371$ & 0.336 & 0.534 & 0.394 & 0.426 & $0 \cdot 355$ & 0.405 & 0.431 & $0 \cdot 394$ & 0.311 & $0 \cdot 324$ & $0 \cdot 383$ & $0 \cdot 386$ & 0.263 & 0.384 & $0 \cdot 397$ & 0.33 \\
\hline 30 & $-0 \cdot 151$ & 0.415 & 0.455 & 0.418 & 0.415 & 0.312 & 0.376 & 0.271 & 0.361 & 0.213 & 0.319 & 0.347 & $0 \cdot 238$ & 0.492 & $0 \cdot 394$ & 0.468 & 0.347 & 0.311 & 0.39 \\
\hline 31 & $-0 \cdot 015$ & $0 \cdot 316$ & 0.396 & 0.372 & 0.449 & 0.408 & 0.370 & $0 \cdot 305$ & 0.337 & 0.344 & 0.327 & 0.312 & 0.290 & 0.457 & 0.419 & $0 \cdot 386$ & 0.496 & 0.411 & 0.42 \\
\hline 32 & $-0 \cdot 103$ & $0 \cdot 170$ & 0.231 & 0.281 & 0.405 & 0.113 & $0 \cdot 107$ & $0 \cdot 102$ & 0.195 & $0 \cdot 118$ & 0.224 & 0.173 & 0.189 & 0.319 & $0 \cdot 232$ & 0.252 & 0.224 & $0 \cdot 230$ & $0 \cdot 23$ \\
\hline 33 & $0 \cdot 107$ & 0.309 & 0.313 & 0.134 & $0 \cdot 230$ & 0.310 & $0 \cdot 305$ & $0 \cdot 320$ & 0.337 & 0.373 & 0.325 & 0.362 & $0 \cdot 342$ & $0 \cdot 450$ & $0 \cdot 350$ & 0.253 & $0 \cdot 303$ & 0.386 & $0 \cdot 37$ \\
\hline 34 & $0 \cdot 141$ & 0.333 & 0.414 & 0.222 & 0.243 & 0.304 & 0.308 & 0.292 & 0.284 & 0.313 & $0 \cdot 240$ & $0 \cdot 366$ & 0.234 & $0 \cdot 367$ & $0 \cdot 383$ & 0.331 & 0.213 & 0.343 & $0 \cdot 28$ \\
\hline 35 & 0.053 & $0 \cdot 255$ & $0 \cdot 204$ & $0 \cdot 251$ & $0 \cdot 244$ & $0 \cdot 098$ & 0.366 & $0 \cdot 276$ & 0.323 & 0.253 & 0.373 & 0.398 & $0 \cdot 296$ & 0.401 & $0 \cdot 281$ & $0 \cdot 318$ & 0.235 & $0 \cdot 174$ & $0 \cdot 1 \rightarrow 4$ \\
\hline 36 & 0.097 & $0 \cdot 214$ & $0 \cdot 164$ & $0 \cdot 235$ & 0.193 & $0 \cdot 221$ & 0.215 & $0 \cdot 134$ & 0.203 & $0 \cdot 161$ & 0.220 & 0.157 & $0 \cdot 190$ & $0 \cdot 308$ & $0 \cdot 171$ & $0 \cdot 198$ & $0 \cdot 275$ & $0 \cdot 193$ & $0 \cdot 18$ \\
\hline 37 & $0 \cdot 132$ & 0.398 & 0.380 & 0.415 & 0.365 & 0.423 & 0.438 & 0.410 & 0.366 & 0.466 & $0 \cdot 350$ & 0.498 & $0 \cdot 386$ & 0.590 & 0.424 & 0.488 & 0.424 & 0.439 & $0 \cdot 33$ \\
\hline 38 & $-0 \cdot 136$ & 0.245 & $0 \cdot 300$ & $0 \cdot 300$ & 0.329 & $0 \cdot 266$ & 0.225 & $0 \cdot 170$ & 0.242 & 0.121 & $0 \cdot 232$ & 0.283 & 0.159 & 0.331 & $0 \cdot 244$ & 0.266 & 0.259 & 0.126 & 0.23 \\
\hline
\end{tabular}


chipping hammer operators and rock drill operators but this was not the case for so called general complaints. The prevalence rate of symptoms in brush saw operators was the same as that in the farmers.

RELATION BETWEEN THE COMPLAINTS AND THE EXTRACTED FACTORS

Table 4 shows the correlation matrix of the 38 complaints in the four exposure groups. Table 5 shows the varimax rotated factor matrix under the estimation of three factors. Factor 1 had a high value of factor loading $(0.7-0.8)$ with $36.9 \%$ contribution ratio in various types of complaints, especially those related to the peripheral nerves, muscles, and joints of the hands. Factor 2 mixed plus and minus values with no characteristic tendency except for relatively high minus values for items of peripheral sensation. Factor 3 was characteristic only of Raynaud's phenomenon, and had a high value.

\section{FACTOR SCORE FOR THE EXTRACTED FACTORS AND THE RELATED CHARACTERISTICS}

A factor score was calculated for each subject using formulas based on the principal factor analysis (see appendix). The mean values of the factor scores for

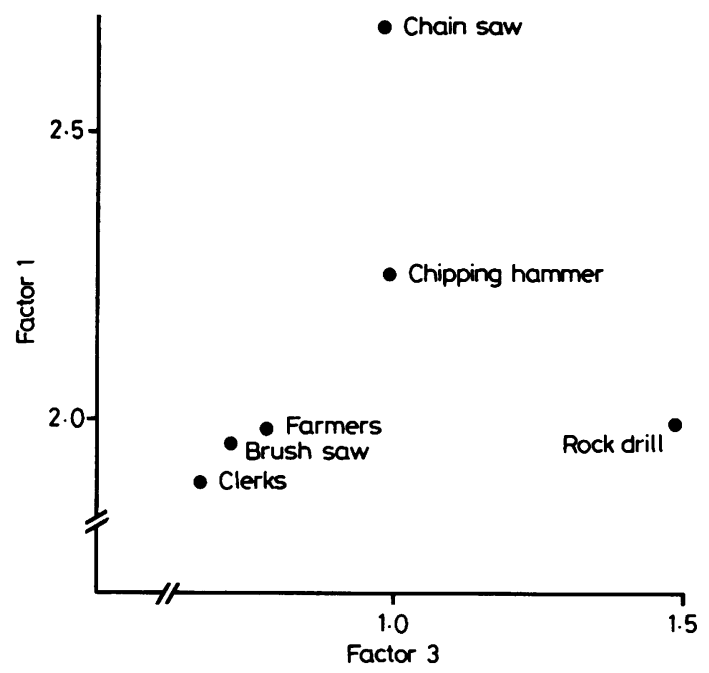

Fig 2 Mean values of factor score plotted in $Z_{1}-Z_{3}$ dimension.

factors 1 and 3 are plotted in the $Z_{1}-Z_{3}$ dimension as shown in fig 2 . The brush saw group was located in the same area as the non-exposed groups. The rock

\begin{tabular}{llllllllllllllllllllll}
\hline 20 & 21 & 22 & 23 & 24 & 25 & 26 & 27 & 28 & 29 & 30 & 31 & 32 & 33 & 34 & 35 & 36 & 37 & 38 & \\
\hline
\end{tabular}


Table 5 Matrix of factor from the 38 items questionnaire

\begin{tabular}{|c|c|c|c|}
\hline Complaints & Factor 1 & Factor 2 & Factor 3 \\
\hline 1 & 0.0772 & -0.2065 & 0.7735 \\
\hline 2 & 0.5858 & -0.0817 & 0.2479 \\
\hline 3 & 0.6593 & -0.0952 & $0 \cdot 0466$ \\
\hline 4 & 0.5121 & 0.2204 & 0.1890 \\
\hline 5 & 0.5743 & $0 \cdot 2352$ & 0.1592 \\
\hline 6 & 0.6007 & $-0 \cdot 1443$ & 0.3892 \\
\hline 7 & 0.6969 & -0.3203 & -0.1678 \\
\hline 8 & 0.6864 & -0.5326 & -0.1425 \\
\hline 9 & 0.7238 & -0.3679 & -0.2935 \\
\hline 10 & 0.6586 & -0.4727 & 0.1203 \\
\hline 11 & 0.7237 & -0.3487 & -0.2537 \\
\hline 12 & 0.6921 & -0.3246 & -0.1478 \\
\hline 13 & 0.5586 & -0.1905 & 0.2196 \\
\hline 14 & 0.7906 & $-0 \cdot 1260$ & $-0 \cdot 1660$ \\
\hline 15 & 0.6313 & $-0 \cdot 1498$ & -0.1216 \\
\hline 16 & 0.6659 & -0.0635 & -0.1961 \\
\hline 17 & 0.6075 & $0 \cdot 1147$ & -0.0026 \\
\hline 18 & 0.6546 & -0.2174 & 0.1945 \\
\hline 19 & 0.6549 & $-0 \cdot 1282$ & -0.0752 \\
\hline 20 & 0.7418 & $-0 \cdot 1662$ & -0.1614 \\
\hline 21 & 0.6742 & 0.2379 & -0.0150 \\
\hline 22 & 0.7265 & 0.2727 & 0.0186 \\
\hline 23 & 0.3165 & 0.3324 & 0.0516 \\
\hline 24 & 0.5968 & 0.2874 & 0.0650 \\
\hline 25 & 0.5964 & 0.0970 & $0 \cdot 1741$ \\
\hline 26 & 0.5883 & 0.2670 & -0.0150 \\
\hline 27 & 0.5233 & 0.3316 & -0.2024 \\
\hline 28 & 0.6111 & 0.2505 & -0.1233 \\
\hline 29 & 0.6344 & 0.1443 & 0.2525 \\
\hline 30 & 0.6579 & 0.3922 & -0.1599 \\
\hline 31 & 0.6643 & 0.2994 & 0.0571 \\
\hline 32 & 0.4228 & 0.4276 & -0.0786 \\
\hline 33 & 0.5108 & -0.0753 & $0 \cdot 1308$ \\
\hline 34 & 0.4859 & -0.0933 & $0 \cdot 1994$ \\
\hline 35 & 0.4999 & 0.1855 & -0.1264 \\
\hline 36 & 0.4006 & 0.3087 & $0 \cdot 1170$ \\
\hline 37 & 0.6764 & 0.0212 & $0 \cdot 1844$ \\
\hline 38 & 0.4640 & 0.3849 & $-0 \cdot 1481$ \\
\hline Eigenvalue & $14 \cdot 0314$ & $2 \cdot 6558$ & 1.6449 \\
\hline Ratio of contribution & 0.3693 & 0.0699 & 0.0433 \\
\hline
\end{tabular}

drill group's factor 3 scores were significantly high, as were the factor 1 scores for the chain saw group and the chipping hammer group. It was interesting to find that each exposure group was located in a different area in the $Z_{1}-Z_{3}$ dimension.

Factor scores were calculated for each subject in the whole population from which the group of chain saw operators was drawn $(n=463)$. Figure 3 shows the frequency distribution of factor scores in three groups (with VWF, without VWF but with disturbances of peripheral nerves, muscles, and joints, and farmers). The group of chain saw operators had significantly high scores $(p<0.01)$ for both the VWF group $(n=93)$ and the peripheral neuropathies group $(n=88)$ at the same value in factor 1 . As for factor 3, chain saw operators with VWF had significantly high scores $(p<0.01)$ and the group with peripheral neuropathies had the same score as the group of farmers.

\section{Discussion}

In many previous studies subjective symptoms have

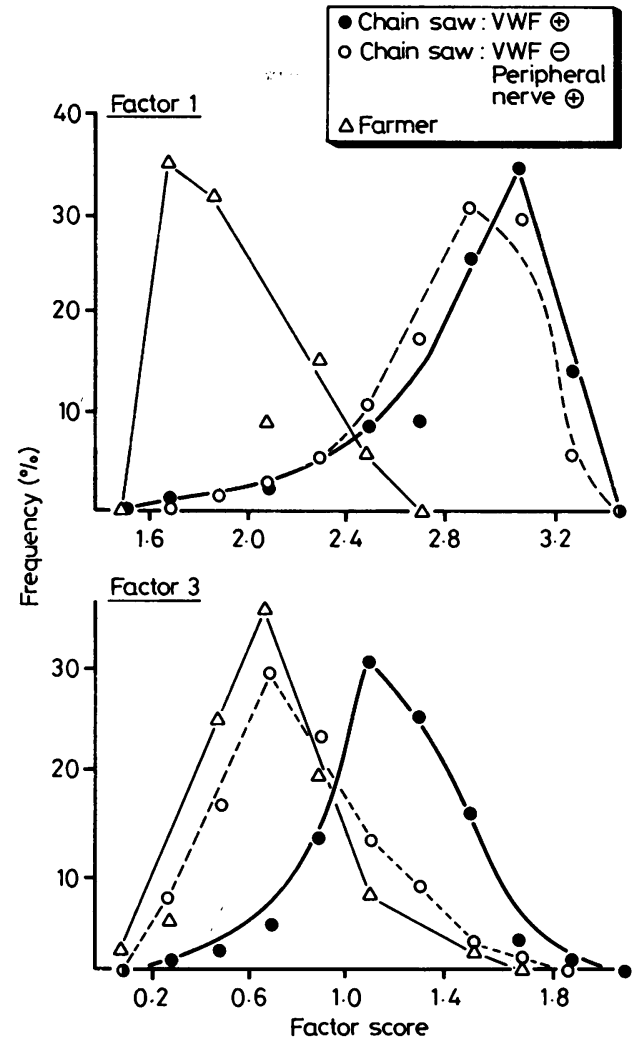

Fig 3 Frequency distribution of factor score related to grade of symptom.

been observed that suggested the presence of some disorder. An awareness of the significance of these symptoms among those exposed to vibration may make these symptoms the most effective simple indicator of vibration induced damage. This should be followed by more advanced diagnostic procedures appropriate to the symptoms, however, although the validity of these procedures are uncertain at present. It may be valuable, therefore, to use subjective complaints to compare pathological patterns among different groups exposed to vibration and to discuss the relation between the complaints and the workloads.

It has been reported that the effects of vibration depend on the physical characteristics of the tools used, and that they vary not only with the dominant frequency but also with the harmonics. Depending on the dominant frequency, the following effects might be observed: at frequencies below $40 \mathrm{~Hz}$ and with amplitudes of several centimetres, osteoarticular lesions may occur; at frequencies between $40 \mathrm{~Hz}$ and $300 \mathrm{~Hz}$ and amplitudes of the order of 
$1 \mathrm{~mm}$, vasomotor disturbances, notably of the hands, may appear after several years exposure; at frequencies of more than $300 \mathrm{~Hz}$ and amplitudes of the order of $0.01 \mathrm{~mm}$, persistent disorders might appear after a few weeks. In practice many vibrating tools have a complex frequency distribution with wide ranges. Also some related working factors, such as temperature in the work place, working posture and weight of tools may modify the pathological findings in vibration disease. Matsumoto et al suggested that the circulatory system was largely influenced by exposure to vibration of high energy at middle to high frequency and by the handling of tools in a cold environment, and that the nervous system was affected by vibration energy at low to middle frequency, based on the results of a comparative study of some vibrating tools. ${ }^{17}$ In the present study we have tried to evaluate a wide variety of symptoms in subjects using vibrating tools by multivariate statistical methods. From a wide variety of symptoms a principal component related to peripheral nerves, muscle, and joints and a component for peripheral circulation were extracted specifically and separately. The complaints of the rock drillers reflected a peripheral circulatory factor whereas those of the chain saw operators and the chipping hammer operators presented a complex factor of nerves, muscles, and joints. It was considered that the peripheral circulatory factor might be effected by the weighted vibration level itself and that the factor related to peripheral nerves, muscles, and joints might be strongly affected by working conditions that were not always similar when operating the vibrating tools.

The validity of the analysis must depend on the reliability of the information gathered from the questionnaire. It would be interesting if material obtained from other groups exposed to vibration was analysed by the method seen here and compared with the results of objective tests in order to obtain more universally applicable results.

Requests for reprints to: Makoto Futatsuka, Department of Public Health, Kumamoto University Medical School, Kumamoto 860, Japan.

\section{Appendix}

Factor score was calculated for each subject with the following formula.

$$
\begin{aligned}
& \mathrm{Z}_{1}=0.006 \mathrm{x}_{1}+0.042 \mathrm{x}_{2}+0.047 \mathrm{x}_{3}+0.036 \mathrm{x}_{4}+ \\
& 0.041 \mathrm{x}_{5}+0.043 \mathrm{x}_{6}+0.050 \mathrm{x}_{7}+0.049 \mathrm{x}_{8}+ \\
& 0.052 \mathrm{x}_{9}+0.047 \mathrm{x}_{10}+0.052 \mathrm{x}_{11}+0.049 \mathrm{x}_{12}+ \\
& 0.040 \mathrm{x}_{13}+0.056 \mathrm{x}_{14}+0.045 \mathrm{x}_{15}+0.047 \mathrm{x}_{16}+ \\
& 0.043 \mathrm{x}_{17}+0.047 \mathrm{x}_{18}+0.047 \mathrm{x}_{19}+0.053 \mathrm{x}_{20}+
\end{aligned}
$$

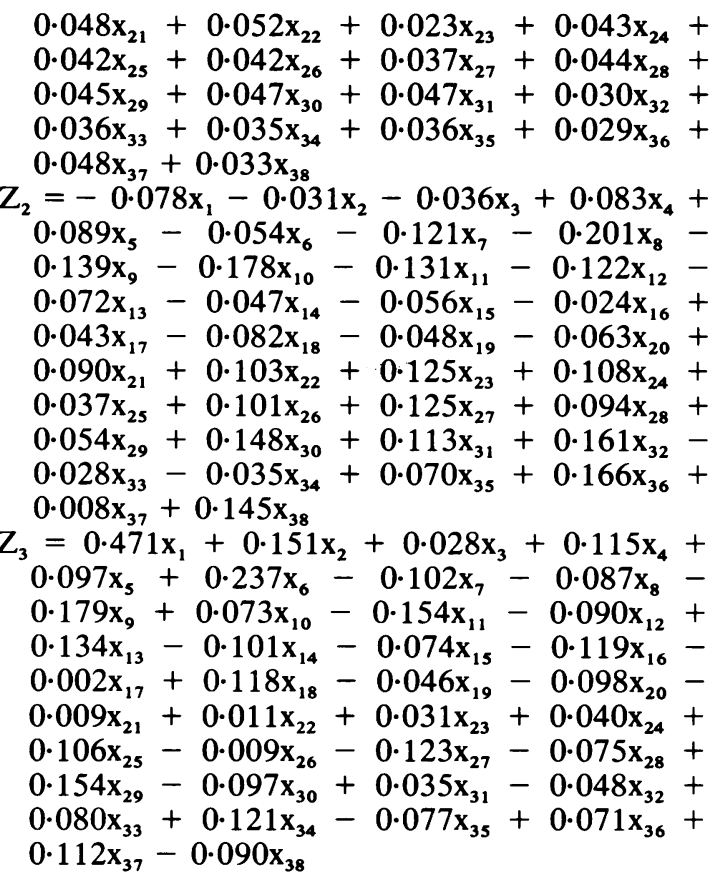

\section{References}

' Taylor W. The vibration syndrome. London: Academic Press, 1974.

${ }^{2}$ Taylor W, Pelmear PL. Vibration white finger in industry. London: Academic Press, 1975.

${ }^{3}$ Bianchi G, Frolov KV, Oledzki A. Man under vibration suffering and protection. Amsterdam: Elsevier Scientific Publication, 1981.

4 Brammer AJ, Taylor W. Vibration effects on the hand and arm in industry. New York: Winley-Interscience Publication, 1982.

${ }^{5}$ Griffin MJ. Vibration injuries of the hand and arm: their occurrence and the evolution of standards and limits. London: HSE, 1980. (Health and Safety executive research paper 9.)

- Futatsuka M, Sakurai T, Ariizumi M. Preliminary evaluation of dose-effect relationships for vibration induced white finger in Japan. Int Arch Occup Environ Health 1984;54:201-21.

' Yamada S, Takagi S. Vibration hazards. In: Sobue I, ed. Naikagaku Taikei 59.B. Tokyo: Hirokawa Shoten, 1976:248-80.

${ }^{8}$ International Labour Office. Protection of workers against noise and vibration in the working environment. ILO code of practice. Geneva: ILO, 1977.

' Futatsuka M. Epidemiological studies of vibration disease due to brush saw operation. Int Arch Occup Environ Health 1984;54:251-60.

${ }^{10}$ Matsumoto T, Yamada S, Hisanaga N, Harada N, Kaneda K. On vibration hazards in rock-drill operators of a metal mine. Jpn J Ind Health 1977;19:256-65.

"Gotoh T. Vibration disease due to chipping hammer among stone cutters. Journal of the Kurume Medical Association $1980 ; 45: 862-80$. 
12 Futatsuka M, Ueno T. Analytical study on the vibration exposure and vibration induced white finger due to operating chain saw. $J$ Occup Med (in press).

${ }^{13}$ Okuno C. Multivariate statistical methods. Tokyo: Nikkagiren, 1976.

14 Wijting JP, Wollack S, Smith PC. A factor analytic study of subjective components of activation. Perceptual and Motor Skills 1970;31:635-40.

is Futatsuka M. Classification of vibration disease in Japan. In:
Gemne G, Taylor W, eds. Hand-arm vibration and the central autonomic nervous system. Journal of Low Frequency Noise and Vibration 1983;1:42-6. (Special issue.)

${ }^{16}$ Drogicina EA, Razumov IK. Vibration. In: Encyclopaedia of occupational health and safety. Geneva: International Labour Office, 1972:1463-5.

17 Matsumoto T, Yamada S, Harada N. A comparative study of vibration hazards among operators of vibrating tools in certain industries. Arch hig rada toksikol 1979;30:701-7.

\section{Vancouver style}

All manuscripts submitted to the $B r J$ Ind Med should conform to the uniform requirements for manuscripts submitted to biomedical journals (known as the Vancouver style).

The $\mathrm{Br} J$ Ind Med, together with many other international biomedical journals, has agreed to accept articles prepared in accordance with the Vancouver style. The style (described in full in $\mathrm{Br}$ Med J, 24 February 1979, p 532) is intended to standardise requirements for authors.

References should be numbered consecutively in the order in which they are first mentioned in the text by Arabic numerals above the line on each occasion the reference is cited (Manson' confirmed other reports ${ }^{2-5} \ldots$.). In future references to papers submitted to the $\mathrm{Br} J$ Ind Med should include: the names of all authors if there are six or less or, if there are more, the first three followed by $e t$ al; the title of journal articles or book chapters; the titles of journals abbreviated according to the style of Index Medicus; and the first and final page numbers of the article or chapter.

Examples of common forms of references are:

' International Steering Committee of Medical Editors. Uniform requirements for manuscripts submitted to biomedical journals. $\mathrm{Br}$ Med $\mathrm{J} 1$ 1979; 1:532-5.

${ }^{2}$ Soter NA, Wasserman SI, Austen KF. Cold urticaria: release into the circulation of histamine and eosinophil chemotactic factor of anaphylaxis during cold challenge. $N$ Engl $J$ Med 1976;294:687-90.

${ }^{3}$ Weinstein L, Swartz MN. Pathogenic properties of invading micro-organisms. In: Sodeman WA Jr, Sodeman WA, eds. Pathologic physiology: mechanisms of disease. Philadelphia: W B Saunders, 1974:457-72. 